\title{
Ozone Destruction of Hanford Site Tank Waste Organics
}

\author{
S. A. Colby \\ Date Published \\ April 1993
}

\section{DISCLAIMER}

\begin{abstract}
This report was prepared as an account of work sponsored bo
Government. Neither the United States Governmensored by an agency of the United States employees, makes any warranty, States Government nor any agency thereof, nor any of thei bility for the accuracy, completeness, or usefulness of assumes any legal liability or responsiprocess disclosed, or represents that its use woulness of any information, apparatus, product, or ence herein to any specific commercial product, process, infringe privately owned rights. Refermendation, or or otherwise does not necessarily constitute or imply trade name, trademark, and opin, or favoring by the United States Governo or imply its endorsement, recomUnited States of authors expressed herein do not necessarily agency thereof. The views United States Government or any agency thereof.
\end{abstract}

Prepared for the U.S. Department of Energy Office of Environmental Restoration and Waste Management

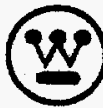

Westinghouse Hantord Company

P.O. Box 1970

Richland, Washington 99352

Hanford Operations and Engineering Contractor for the

U.S. Department of Energy under Contract DE-AC06-87RL10930

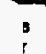




\section{DISCLAIMER}

Portions of this document may be illegible in electronic image products. Images are produced from the best available original document. 


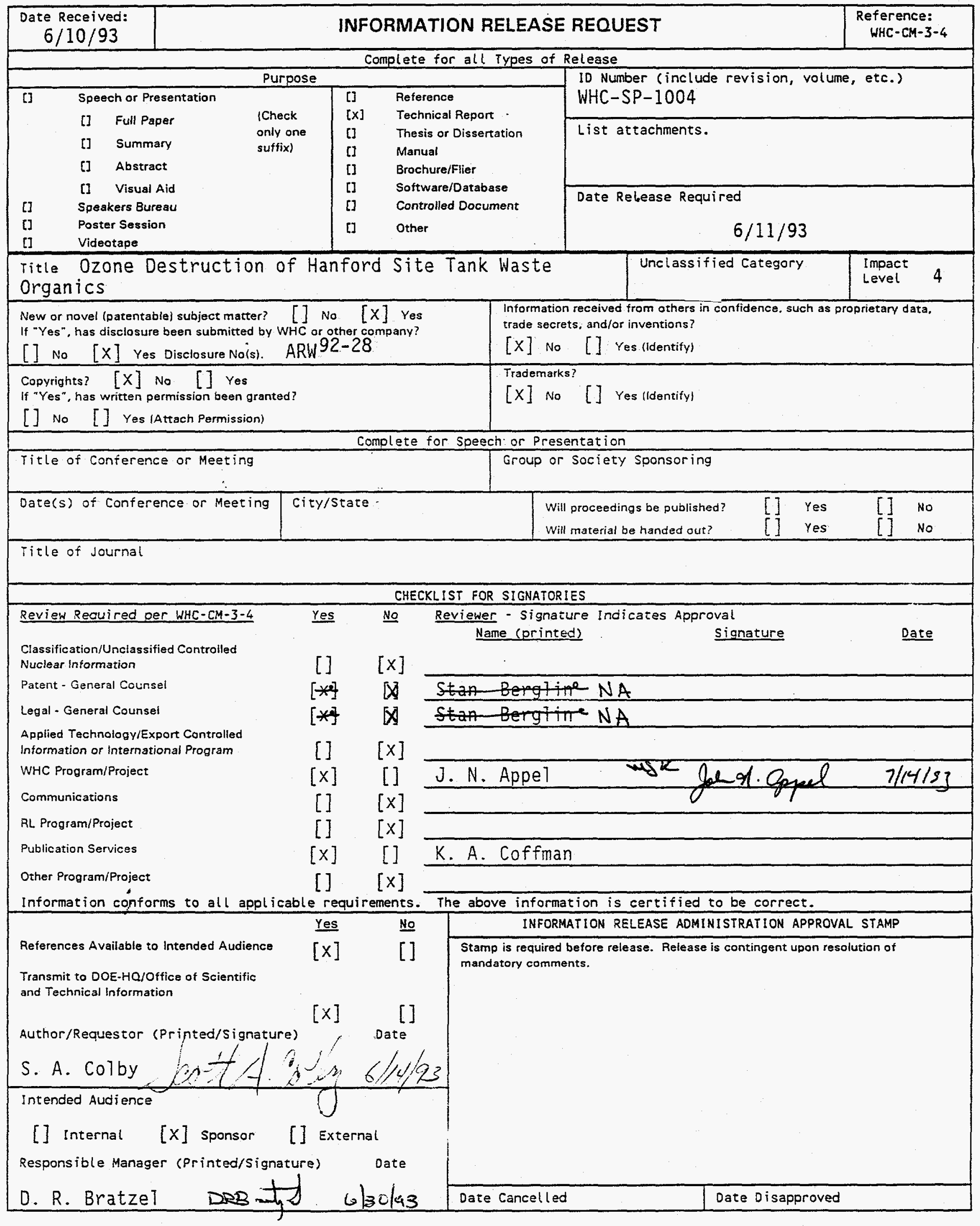


WHC-SP-1004

\title{
OZONE DESTRUCTION OF HANFORD SITE TANK MASTE ORGANICS
}

\author{
S. A. Colby
}

\section{ABSTRACT}

Ozone processing is one of several technologies being developed to meet the intent of the Secretary of the U.S. Department of Energy, Decision on the Programmatic Approach and Near-Term Actions for Management and Disposal of Hanford Tank Waste Decision Statement, dated December 20, 1991, which emphasizes the need to resolve tank safety issues by destroying or modifying the constituents (e.g., organics) that cause safety concerns. As a result, the major tank treatment objectives on the Hanford Site are to resolve the tank safety issues regarding organic compounds (and accompanying flammable gas generation), which all potentially can react to evolve heat and gases.

This report contains scoping test results of an alkaline ozone oxidation process to destroy organic compounds found in the Hanford Site's radioactive waste storage tanks. Ozone has been used for the past 100 years in the municipal waste industry to oxidize trace organics. Ozone is created by passing oxygen gas through a corona electric field. Industrial equipment can mass produce ozone gas in concentrations up to 10 weight percent. Because ozone gas is relatively dilute, large quantities of carrier gas are needed, especially for treating wastes that contain high organic concentrations.

A laboratory scale continuous-stirred tank reactor contacted gaseous ozone with a simulated waste at near ambient conditions of temperature and pressure. Estimated scale-up of the analytical data indicates that 
70,000 kilowatt hours per day of power and 90,000 kilograms per day of oxygen carrier gas would be required to treat 20 million liters of $3: 1$ diluted tank waste per year (i.e., a 20-gallon-per-minute plant operating 180 days per year). Note the estimated scale-up has been developed for comparison of this candidate process to other processes and is based on preliminary laboratory testing.

Analytical data indicate that the ozone reactor provides sufficient mass transport to use greater than 90 percent of the ozone to oxidize waste simulant constituents. Additionally, the process performed similarly under varying operating conditions (e.g., temperature and hydroxide concentration) indicating that the process is robust. The likely by-products from ozone oxidation of organics are carbonate and small carbon chain refractory organics that are considered to pose minimal safety concerns. A full-scale process, however, would require large volumes of gas to contact the relatively dilute ozone with feedstock waste. 


\section{CONTENTS}

1.0 INTRODUCTION . . . . . . . . . . . . . . . . . . . . . . . . 1

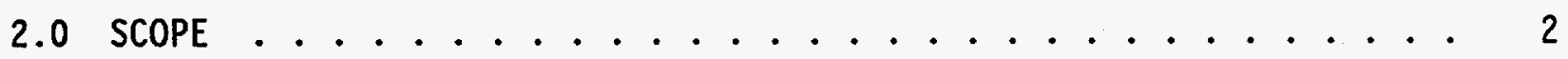

3.0 EXPERIMENTAL . . . . . . . . . . . . . . . . . . . . 2

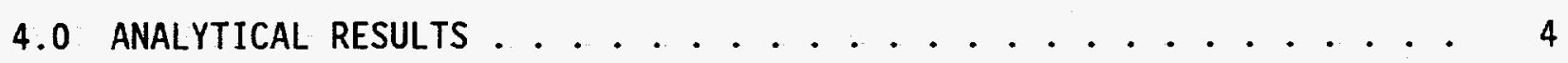

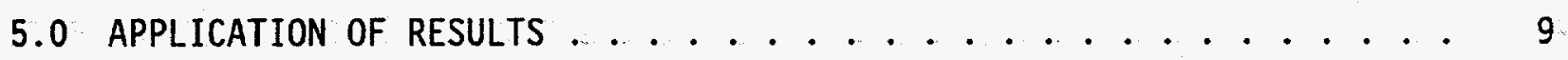

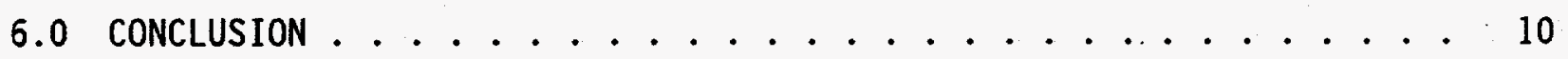

7.0 REFERENCES . . . . . . . . . . . . . . . . . . . . . 10

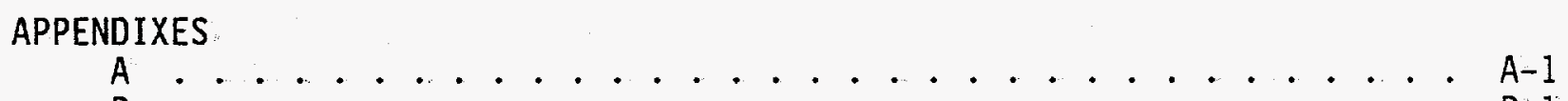

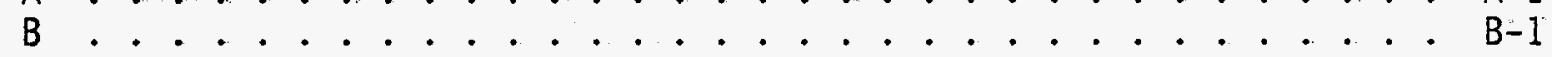

\section{LIST OF FIGURES}

1 The Hanford Site Area Map . . . . . . . . . . . . . . . . . . 1

2 Ozone Process Laboratory Flow Diagram . . . . . . . . . . . . 3

3 Prototype Ozone Reactor . . . . . . . . . . . . . . . . 5

4 Ozone Oxidation of Surrogate Organic Compounds in a Simulated

Tank 241-SY-101 Waste ...................... . 5

5 Effect of Varying Operating Parameters on Reactor Performance Based on Ethylenediamenetetraacetic Acid . . . . . . . . . . . . 7

6 Ozone Reduction of Chemical Oxygen Demand Based on Ethylenediamenetetraacetic Acid . . . . . . . . . . . . . 8

7 Preliminary Full-Scale Ozone Process Mass Balance . . . . . . . . 9

8 Simplified Ozone Facility Layout . . . . . . . . . . . . . . 10

\section{LIST OF TABLES}

A-1 Tank 241-SY-101 Simulant Composition . . . . . . . . . . . A-5 
WHC-SP-1004

\section{LIST OF TERMS}

COD

CSTR

EDTA

TOC chemical oxygen demand

continuous-stirred tank reactor ethylenediamenetetraacetic acid total organic carbon 
WHC-SP-1004

\section{OZONE DESTRUCTION OF HANFORD SITE TANK WASTE ORGANICS}

\subsection{INTRODUCTION}

The 1,400- $\mathrm{km}^{2}$ Hanford Site is located in southeastern Washington State, near the Columbia River. Figure 1 shows the location of the Hanford Site in Washington State and the separations area on the Site where the waste storage tanks are located.

Spent nuclear fuel has been processed at the Hanford Site to recover nuclear material since the 1940 's. As a result, radioactive waste has been generated and stored on the Site in underground tanks. Presently, 177 tanks store 155 million $L$ of radioactive waste that has been generated over the last 40 years (Hanion 1991).

Figure 1. The Hanford Site Area Map.

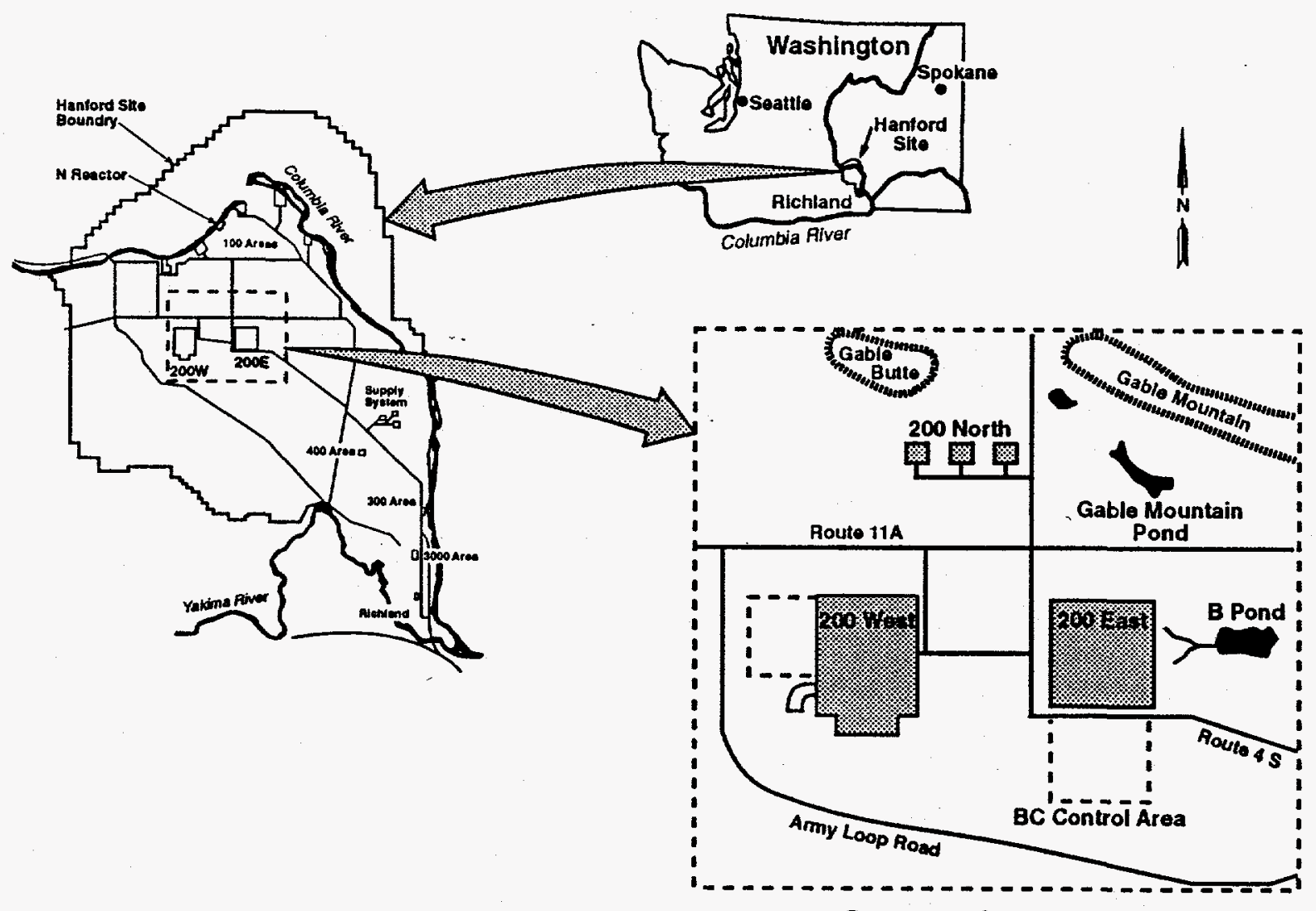

Separations Area 


$$
\text { WHC-SP-1004 }
$$

The Hanford Site tank wastes contain radioactive constituents, making tests with actual waste difficult. Therefore, a nonradioactive waste simulant was prepared in the laboratory to evaluate the prototype homogenizer/ ozonator's ability to oxidize organic compounds. The composition of tank 241-SY-101 was chosen for testing because it poses the highest safety concern of all the Hanford Site's organic containing tanks. The waste simulant composition of tank 241-SY-101 is shown in Appendix A.

The organic compounds added to the simulated waste may not accurately portray the actual organic species contained in the radioactive tank waste. Both radiological and chemical interactions in the waste material may have a) tered the original organics added.

\subsection{SCOPE}

This scoping study evaluated the fundamental premise of alkaline ozone oxidation to destroy surrogate organics contained in a tank 241-SY-101 simulated tank waste. Note that deficiencies in ferrocyanide analysis techniques have delayed tests with simulated wastes from tanks containing ferrocyanide. A comprehensive program based on the results of this initial study is outlined below.

- Tests are needed using actual tank waste to verify the results obtained testing nonradioactive simulants.

- Offgases created from destruction of organics should be sampled and analyzed for constituents and flammability potential (explosion potential in reactor from high concentrations of oxygen and possibly lower concentrations of volatile organic).

- Additional analysis of the treated product is needed to identify metal valence changes and organic byproducts.

- Larger scale tests are needed to determine equipment size for a production facility.

Work on these tasks has been started and scheduled for completion in fiscal year 1993.

\subsection{EXPERIMENTAL}

Testing was performed typically using $100 \mathrm{~mL}$ of nonradioactive simulated waste diluted with $300 \mathrm{~mL}$ of water (or in some cases $400 \mathrm{~mL}$ of water). The waste slurry was placed into the reservoir depicted in the process laboratory flow diagram (Figure 2) and recycled through the ozone reactor at $0.8 \pm 0.01 \mathrm{~L} / \mathrm{min}$. A high recycle rate was used to facilitate obtaining mass transport and kinetic data. The ozone generator continuously supplied a 


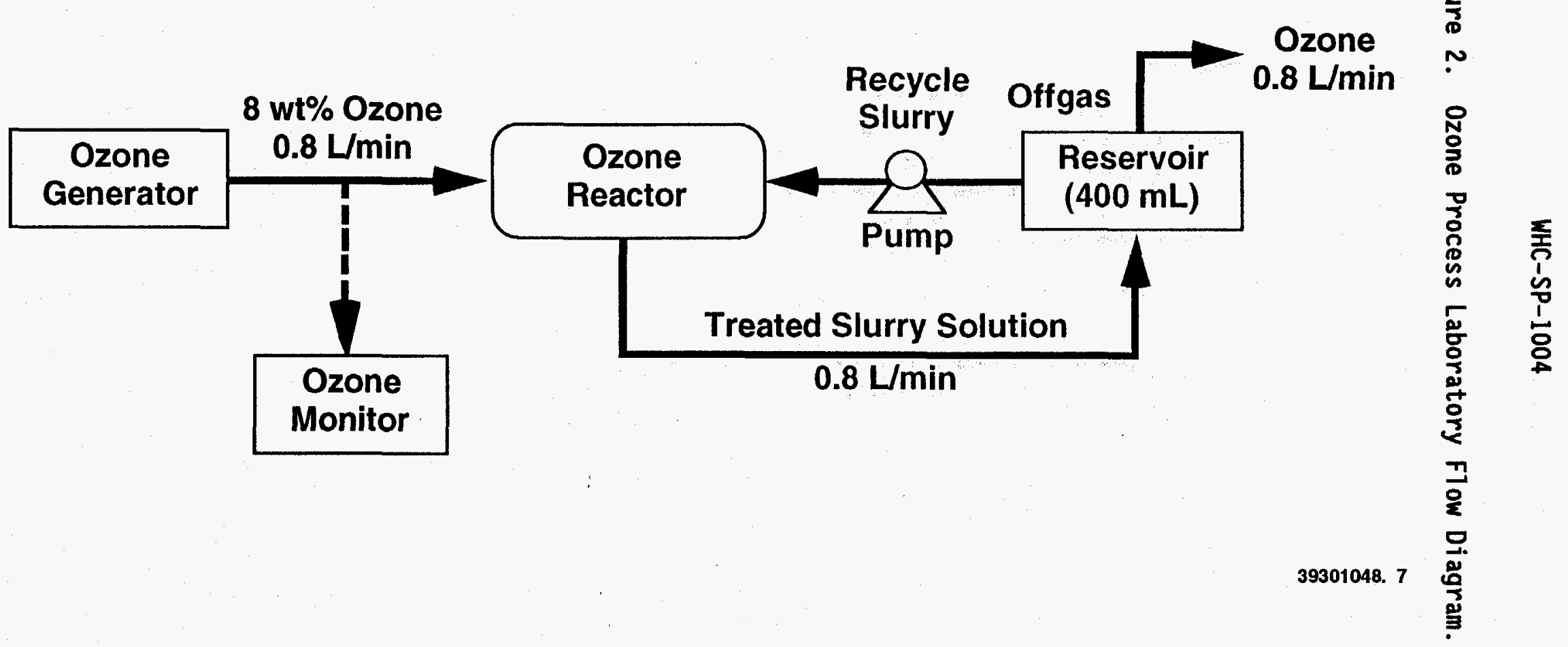


stream of $8 \pm 0.3$ wt\% ozone carried in oxygen at $0.8 \pm 0.05 \mathrm{~L} / \mathrm{min}$ (i.e., $4.5 \mathrm{~g}$ ozone $/ \mathrm{h}$ ). The length of tests varied from between 8 and 20 hours. The ozone gas concentration was measured before entering and after exiting the reactor. Cooling water was supplied to the reactor's mixing shaft to help maintain the simulant temperature at $30 \pm 5{ }^{\circ} \mathrm{C}$. The free hydroxide concentration was 0.1 to 0.2 molar. Adjustment of $\mathrm{pH}$ was used only to replenish hydroxide consumed by oxidation of organic. Total solution volume was measured to compensate analytical results for evaporation of water.

Samples $(5 \mathrm{~mL})$ of the treated simulant were taken every hour. Total organic carbon (TOC) analysis was used to measure the amount of organic oxidized. Chemical oxygen demand $(\mathrm{COD})$ was used to indicate the total amount of ozone oxidation and to indicate ozone use.

To determine the feasibility of using ozone to oxidize tank waste organics, a laboratory scale continuous-stirred tank reactor (CSTR) was employed. Figure 3 depicts the 50-mL-capacity CSTR used for testing.

The CSTR uses short residence times (a few seconds) because of ozone's fast decomposition rate. High-shear mixing in the reactor increases the rate of gaseous ozone's mass transport into solution. The decomposition kinetics of ozone in alkaline medium is in the order of seconds. Because of the fast ozone decomposition kinetics, the ozone/organic reaction rate is limited by mass transport of ozone into solution. In general, the mass transport can be increased by either gas/liquid mixing and/or retention time (Horvath et al. 1985; Bollyky et al. 1981)

An inline static mixer was used downstream of the CSTR to further increase the mass transport of ozone into solution. The static mixer comprises a section of pipe containing internal radial mixing blades that create turbulent flow. Literature indicates that inline static reactors are efficient ozone reactors (Nebel et a1. 1973).

\subsection{ANALYTICAL RESULTS}

Figure 4 delineates the reduction in TOC from ozone treating of the following sodium salts: (1) oxalate, (2) acetate, (3) citrate, and (4) ethylenediamenetetraacetic acid (EDTA) organic. The data indicates that oxalate is not easily oxidized by ozone. The TOC is reduced by $50 \%$ for acetate and citrate, and $90 \%$ for EDTA.

The analytical data suggest that ozone is initially consumed by oxidizing nitrite to nitrate, which represents $70 \%$ of the COD. After significant nitrite oxidation, ozone begins to oxidize the surrogate organic, represented by the TOC depletion shown in Figure 4 .

Ozone likely oxidizes the organics into carbonate and small carbon chain refractory organics. Small carbon chain organics, however, are thought not to pose safety problems regarding flammable gas generation or an organic exothermic reaction. The organic oxidation occurring in the tanks, which generates flammable gas, will presumably cease after ozonation has decomposed 
Figure 3. Prototype Ozone Reactor.

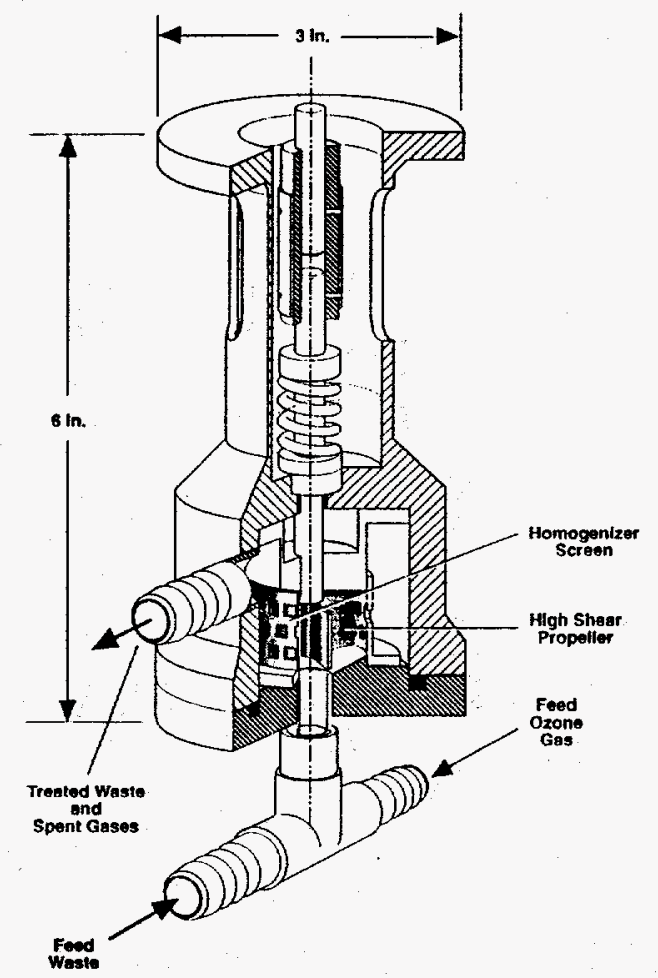

30203128.1 FH

Figure 4. Ozone 0xidation of Surrogate Organic Compounds in a Simulated Tank 241-SY-101 Waste.

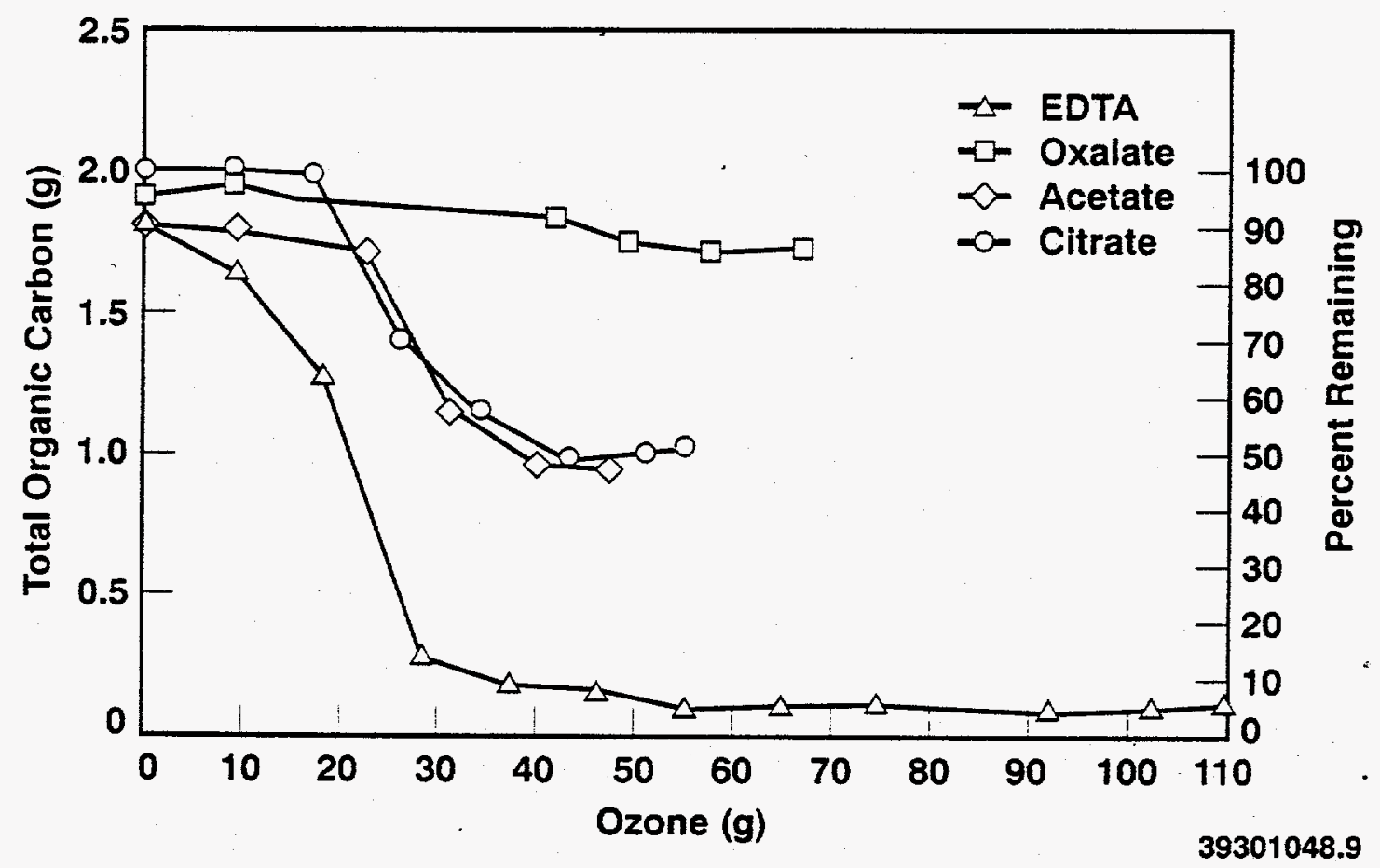


the complex organics into carbonate and small carbon chain compounds. Secondly, the organic species remaining after ozonation are thought to be unable to produce any significant exothermic reaction that could propagate to create heat and gases.

The required level of organic destruction to resolve tank safety issues is not well defined; however, a grout waste feed specification of $1.5 \mathrm{~g} / \mathrm{L}$ TOC (assuming a 1.0 specific gravity) is shown for reference (Hendrickson 1991). In principle, the degree of organic destruction should be linked directly to the safe storage of treated tank waste as follows:

- Quantify the maximum gas generation rate.

- Quantify the maximum exotherm caused from an organic reaction.

- Quantify grout performance using treated product, i.e., compressive strength and toxic characteristic leach procedure tests.

The effect of varying operating conditions on reactor performance are depicted in Figure 5, using EDTA as the surrogate organic. The ozone reactor performed similarly under varying operating conditions.

Raising the solution temperature from $30^{\circ} \mathrm{C}$ to $75^{\circ} \mathrm{C}$ and raising the hydroxide concentration from 0.01 molar to 2 molar appear to have most detrimental affect on ozone use. Ozone decomposition kinetics increase with temperature and hydroxide concentration, which in turn increase the amount of ozone back-reacting to produce diatomic oxygen $\left(\mathrm{O}_{2}\right)$, instead of reacting with oxidizable species in solution (Winters 1981).

Insoluble solids were removed from the simulant by centrifuge. The liquid portion was tested because of a proposed plan to perform a solid-liquid separation by water wash before ozone processing. The solids' presence appears to have little affect on ozone demand. The ozone gas concentration was reduced from 8 wt\% to 4.5 wt\% to determine if the higher concentration of ozone exceeds the solubility limit of ozone in solution and may have impeded ozone's mass transport. The data indicate that ozone demand is similar regardless of the ozone concentrations tested.

The simulant was pretreated using $300 \mathrm{~mL}$ of $30 \mathrm{wt} \%$ hydrogen peroxide in place of the $300 \mathrm{~mL}$ of dilution water, in an attempt to oxidize nitrite to nitrate, thus lowering the ozone demand by $70 \%$. Although nitrite oxidation by hydrogen peroxide was not analyzed for in the test, it appears that the peroxide did not oxidize the nitrite and, therefore, did not significantly reduce the ozone demand. Finally, ozone consumption remained unchanged when $10 \mathrm{~g}$ of manganese dioxide was added to help identify possible ozone decomposition catalysts.

Figure 6 delineates the reduction of $C O D$ by ozone treatment, using EDTA as the surrogate organic. COD measures the amount of oxidation performed by ozone. The reduction of COD occurred linearly, indicating that ozone is the limiting reactant at the higher $\mathrm{COD}$ concentrations tested. 
Figure 5. Effect of Varying Operating Parameters on Reactor Performance Based on Ethylenediamenetetraacetic Acid.
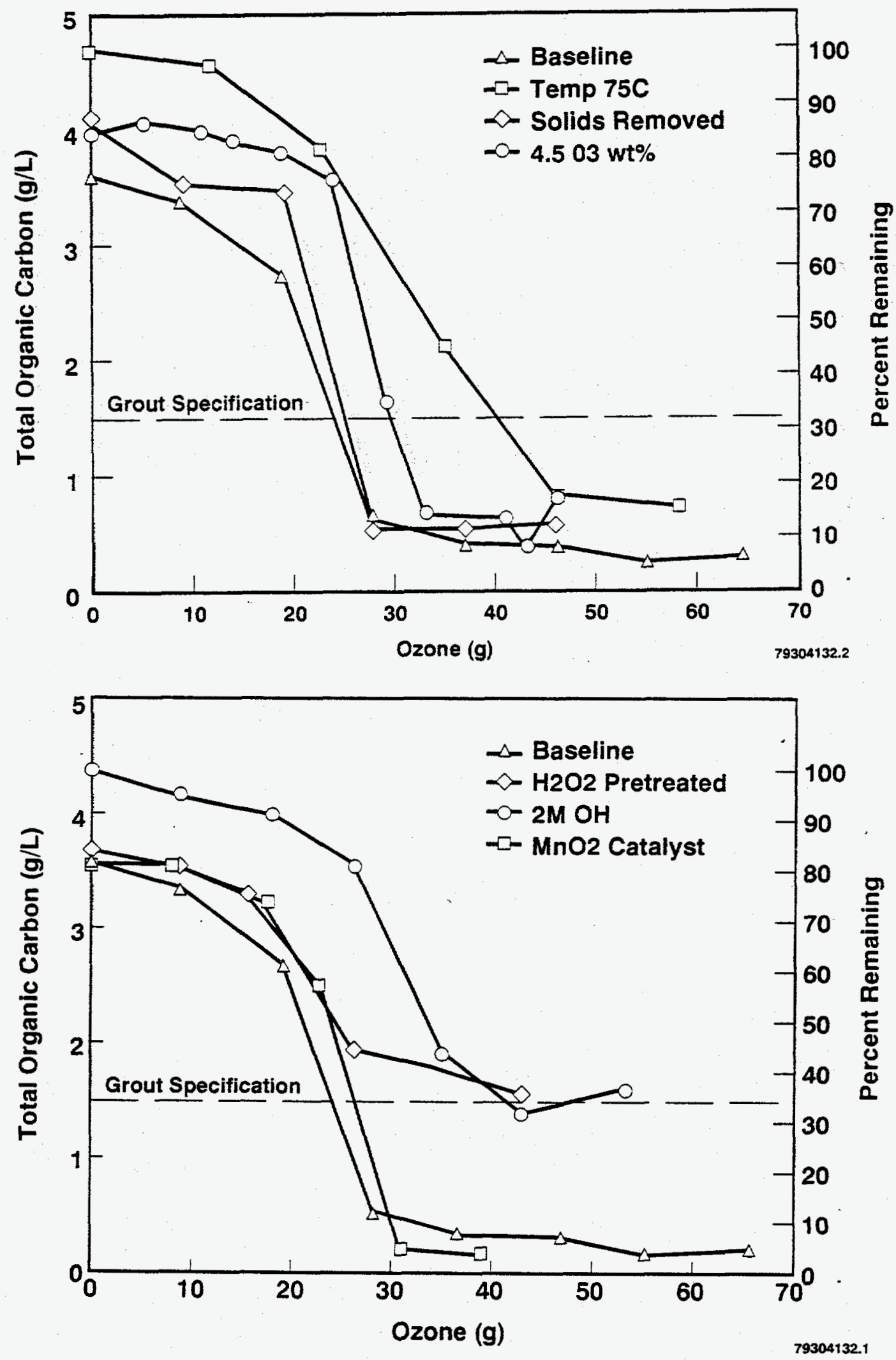
Figure 6. Ozone Reduction of Chemical 0xygen Demand Based on Ethylenediamenetetraacetic Acid.

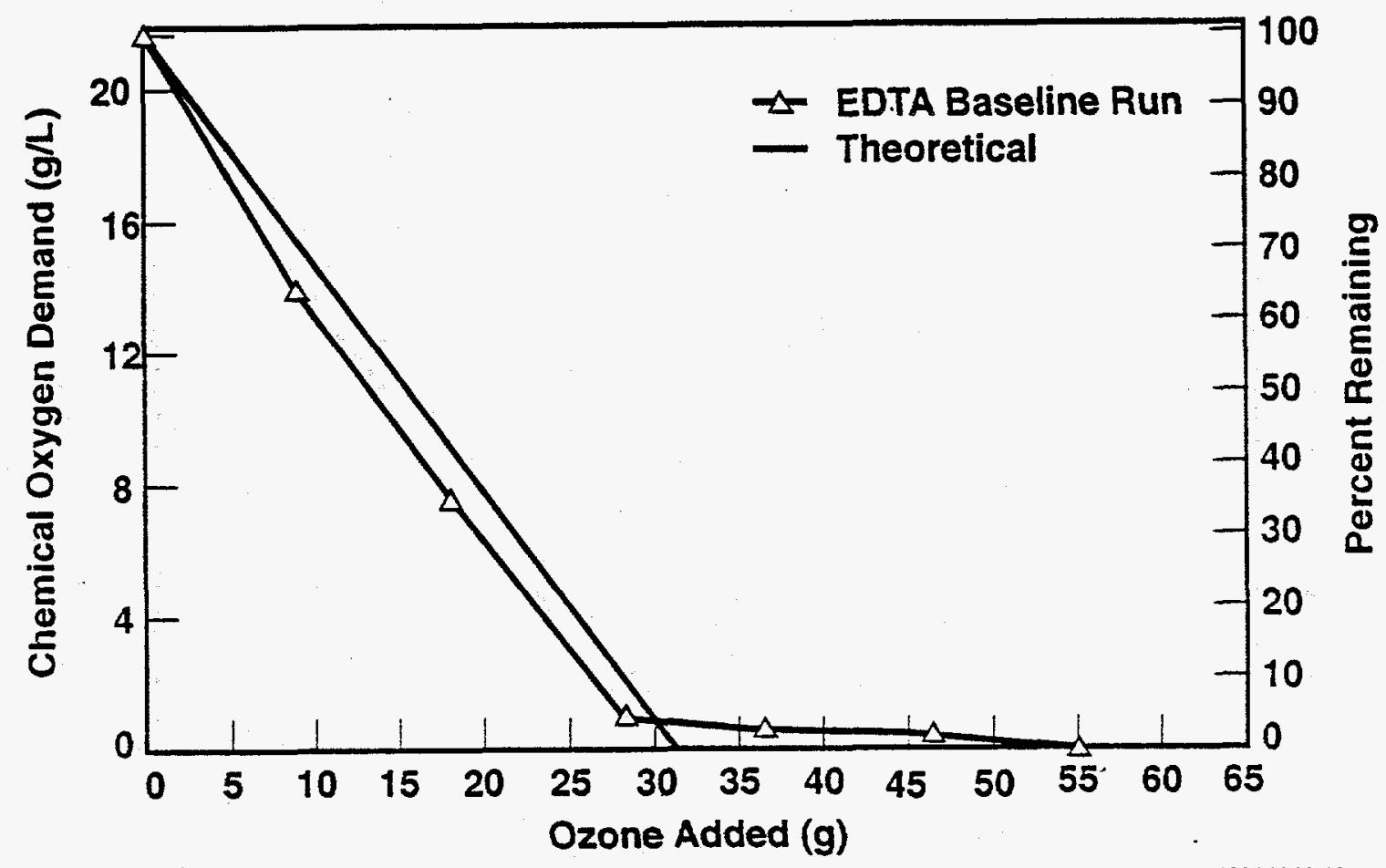

39301048.10

The data indicate that the ozone reactor uses $>90 \%$ of the ozone to oxidize material in the waste simulant. (Appendix $B$ contains calculations of ozone use.) Constituents that are oxidized by ozone in the simulant are nitrite, organic, and multivalent metalions. The theoretical reduction of COD by ozone processing portrays more ozone demand than actually was analytically measured. The deviance is contributed to experimental error (Bollyky et a1. 1981).

Several general observations were made during testing that provide insight into the applicability of a large scale alkaline ozone oxidation process. First, if the hydroxide concentration dropped below roughly 0.01 normal, aluminum compounds precipitated, substantially increasing the total volume of solids. The inorganic carbon produced during organic oxidation consumes free hydroxide and, therefore, additions of hydroxide may be needed to prevent excessive solids generation. Second, the ozone concentration in the reactor offgas was measured to be 1 ess than $10 \mathrm{ppm}$, contingent on the hydroxide concentration remaining above $\mathrm{pH} 12$. Ozone decomposition kinetics increase substantially with rising $\mathrm{pH}$. In the experiment, at lower pHs the ozone concentration in the offgas increased substantialiy. Therefore, the simulant $\mathrm{pH}$ was maintained $>\mathrm{pH} 12$ in all experiments. 


\subsection{APPLICATION OF RESULTS}

Estimated scale-up of the analytical data shown in Figure 7 indicate that $70,000 \mathrm{kWh} / \mathrm{d}$ of power and $90,000 \mathrm{~kg} / \mathrm{d}$ of oxygen carrier gas would be required to treat 20 million $L$ of 3:1 diluted tank waste per year (i.e., a 20-gal/min plant operating $180 \mathrm{~d} / \mathrm{yr}$ ). Additionally, a 4,000-L capacity (STR is estimated from direct scale-up of the 50-mL laboratory CSTR. Note that obtaining mass transport properties, similar to the laboratory reactor, on a larger scale is optimistic (i.e., scaling by a factor of 80,000 from the laboratory reactor to a full-scale reactor). In 1 ieu of 1 arger scale tests, the estimated 4,000-L capacity CSTR provides only a rough minimum estimate of equipment size. (Appendix B contains calculations of scale-up from the analytical data.)

An ozone generation facility would supply ozone to a CSTR likely located in a vault. Waste would be transferred from a feed reservoir, contacted with the ozone in the reactor, and routed to a product reservoir. The offgas from the process would be heated to destroy unreacted ozone and volatile organics, filtered to remove particulates, and vented to the atmosphere. Water and hydroxide additions may be used to makeup for water evaporation and hydroxide consumption caused by processing.

Conceptually, the ozone CSTR could be located in a small vault, adjacent to the ozone generation facility and waste reservoirs, as depicted in the simplified facility layout shown in Figure 8. The layout depicted provides one possible concept of how an ozone process might be designed.

Figure 7. Prel iminary Full-Scale Ozone Process Mass Balance.

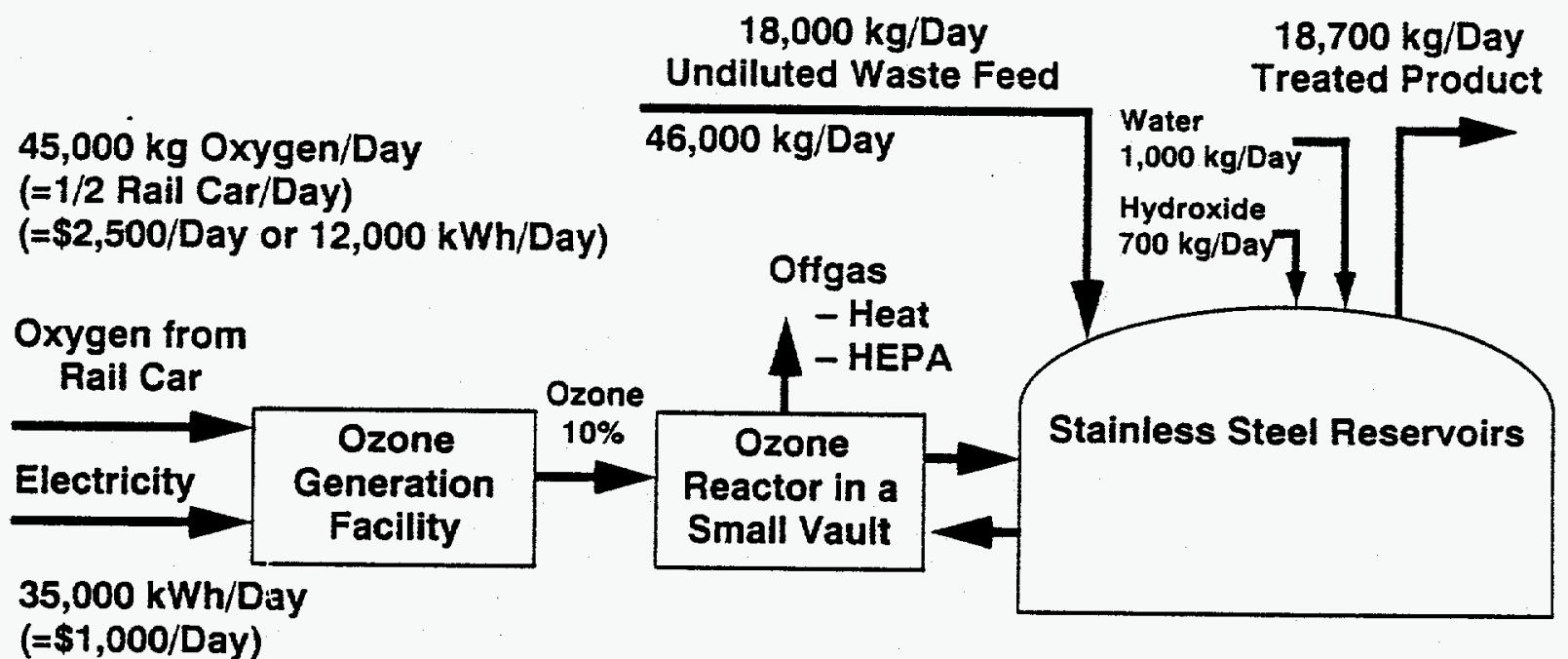

Note: Data obtained from bench scale tests using nonradioactive simulated tank waste. 
Figure 8. ' Simplified Ozone Facility Layout.

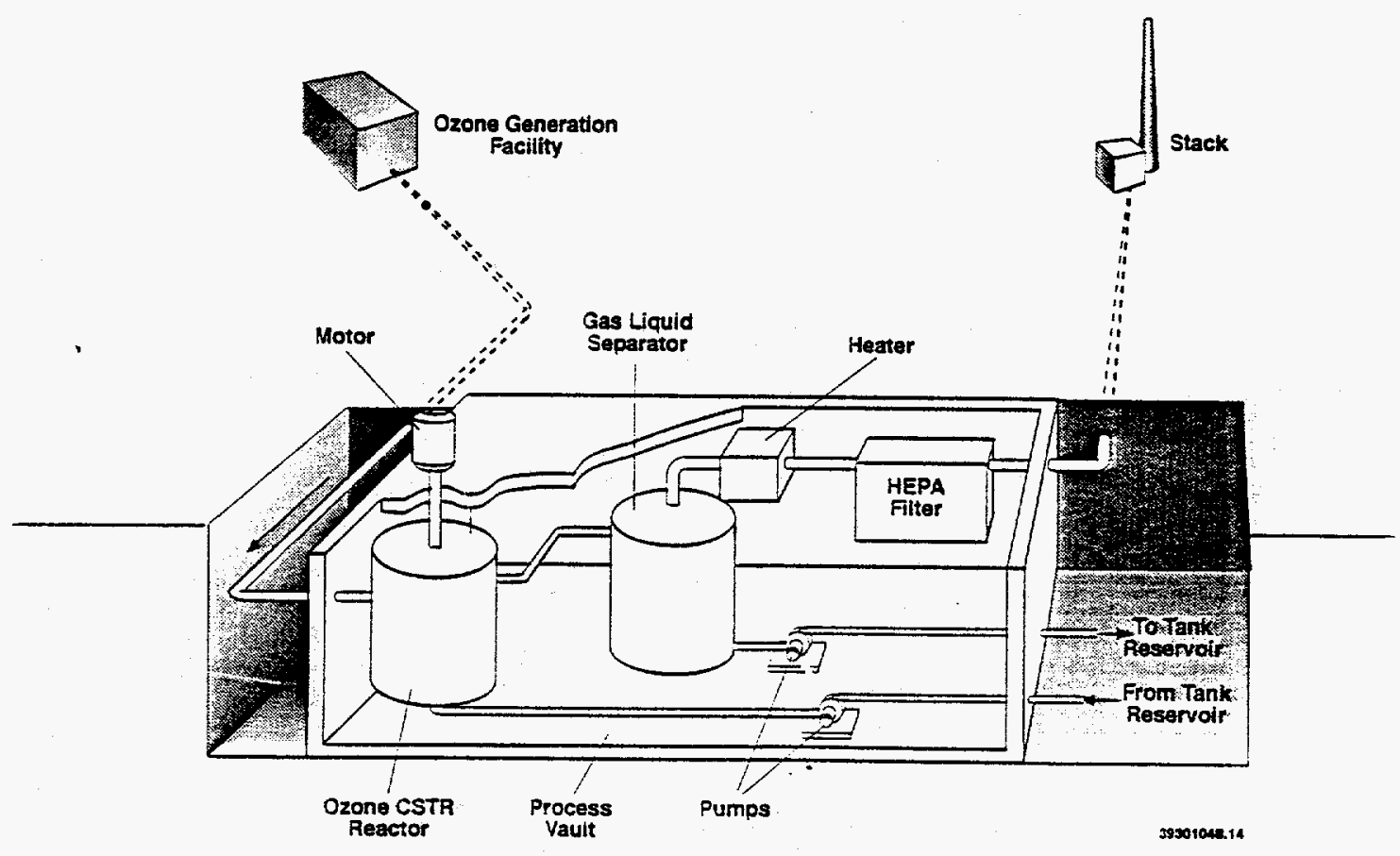

\subsection{CONCLUSION}

Scoping tests show that alkaline ozone oxidation can destroy surrogate organics contained in a tank 241-SY-101 nonradioactive waste simulant into inorganic carbonate and smaller carbon chain refractory organics. Estimated scale-up of the analytical results indicates that the reactor and ancillary equipment are conceptually compact, facilitating a process vault concept.

\subsection{REFERENCES}

Bollyky, J. L., and M. M. Beary, 1981, Ozone Mass Transfer and Kinetics Experiments, RHO-C-47, Rockwell Hanford Operations, Richland, Washington.

DOE, 1991, Decision on the Programmatic Approach and Near-Term Actions for Management and Disposal of Hanford Tank Waste, Secretary of Energy Decision Statement, December 20, 1991, U.S. Department of Energy, Washington, D.C.

Hanlon, B. M., 1991, Tank Farm Surveillance and Waste Status Report for April 1991, WHC-EP-0182-37, Westinghouse Hanford Company, Richland, Washington.

Hendrickson, D. W., 1991, Grout Treatment Facility Waste Feed Acceptance Criteria, WHC-SD-WM-RD-001, Rev. 1, Westinghouse Hanford Company, Richl and, Washington. 
Horvath, M., L. Bilitzky, and J. Huttner, 1985, Ozone, Oxygen and Dissousgas Company, Budapest, Hungary.

Nebe1, C., P. C. Unangst, and R. D. Gottschling, 1973, An Evaluation of Various Mixing Devices for Dispersing Ozone in Water, The Welsbach Corporation, Philadelphia, Pennsylvania.

Winters, W. I., 1981, Effect of $\mathrm{pH}$ on the Destruction of Complexants With Ozone in Hanford Nuclear Waste, RHO-SA-203, Rockwell Hanford Operations, Richl and, Washington. 
WHC-SP-1004

This page intentionally left blank. 
WHC-SP-1004

APPENDIX A

PROCEDURE FOR MAKING TANK 241-SY-101 WASTE SIMULANT

A-1 
WHC-SP-1004

This page intentionally left blank. 


\section{APPENDIX A \\ PROCEDURE FOR MAKING TANK 241-SY-101 MASTE SIMULANT}

The simulant recipe below is representative of tank 241-SY-101 which is presently releasing flammable gas, thus rendering the tank an unresolved tank safety issue. The composition was derived from the recent window $C$ analytical results obtained from core sampling the tank.

The following procedure will be used to make the waste simulant:

1. Mix the following acids into a $4-L$ beaker.

\begin{tabular}{|c|c|c|}
\hline Chemical & Molarity & $\mathrm{mL}$ \\
\hline $\mathrm{HNO}_{3}$ & 16 & 245. \\
\hline $\mathrm{HCL}$ & 12 & 34. \\
\hline $\mathrm{HF}$ & 27 & 1. \\
\hline
\end{tabular}

2. Add the following chemicals to the acid solution.

\begin{tabular}{|c|c|}
\hline Chemical & g \\
\hline $\mathrm{NaAlO}_{2}$ & 150. \\
\hline $\mathrm{FeSO}_{4}-\mathrm{H}_{2} \mathrm{O}$ & 0.25 \\
\hline $\mathrm{Ca}\left(\mathrm{NO}_{3}\right)_{2}-4 \mathrm{H}_{2} \mathrm{O}$ & 6.25 \\
\hline $\mathrm{Cr}_{2} \mathrm{O}_{3}$ & 1.16 \\
\hline $\mathrm{ZnO}$ & 0.18 \\
\hline $\mathrm{NiSO}_{4}-6 \mathrm{H}_{2} \mathrm{O}$ & 0.45 \\
\hline $\mathrm{NaH}_{2} \mathrm{PO}_{4}-\mathrm{H}_{2} \mathrm{O}$ & 12.7 \\
\hline $\mathrm{Mo}\left(\mathrm{OH}_{3}\right.$ & 0.21 \\
\hline $\mathrm{Sr}\left(\mathrm{NO}_{3}\right)_{2}$ & 0.21 \\
\hline $\mathrm{CsCl}$ & 0.84 \\
\hline
\end{tabular}

3. Slowly add $\mathrm{NaOH}$ to $\mathrm{pH} 9$ to 12. 
WHC-SP-1004

4. Add the following chemicals to the solution:

\begin{tabular}{|c|c|}
\hline Chemical & g \\
\hline $\mathrm{Na}_{2} \mathrm{CO}_{3}$ & 62.4 \\
\hline $\mathrm{NaOH}$ & 100. \\
\hline $\mathrm{KOH}$ & 8.21 \\
\hline $\mathrm{NH}_{4}(\mathrm{OH})$ & 1.67 \\
\hline $\mathrm{NaNO}_{2}$ & 330. \\
\hline
\end{tabular}

5. Add ONE of the following organic compounds, depending on the test.

\begin{tabular}{|c|c|c|}
\hline $\begin{array}{c}\text { Organic } \\
\text { compound }\end{array}$ & $\begin{array}{c}\text { Test } \\
\text { sequence }\end{array}$ & $g$ \\
\hline $\mathrm{Na}_{4}$ EDTA & 1 & 57. \\
\hline Oxalate & 2 & 103. \\
\hline Citrate & 3 & 49. \\
\hline Glycol & 4 & 58. \\
\hline
\end{tabular}

6. Add water to make $1 \mathrm{~L}$.

7. Blend the solution at $60^{\circ} \mathrm{C}$ for one hour. 
WHC-SP-1004

The simulant composition is listed in Table A-1.

Table A-1. Undiluted

Tank 241-SY-101 Simulant

Composition.

\begin{tabular}{|c|c|}
\hline Chemicals & $\begin{array}{c}\text { Concentration } \\
(\text { gmol/L) }\end{array}$ \\
\hline $\mathrm{Na}$ & 14.5 \\
\hline $\mathrm{NO}_{3}$ & 3.97 \\
\hline $\mathrm{SO}_{4}$ & 0.0026 \\
\hline $\mathrm{NO}_{2}$ & 4.78 \\
\hline $\mathrm{CO}_{3}$ & 0.59 \\
\hline $\mathrm{OH}$ & 2.63 \\
\hline $\mathrm{Cr}$ & 0.15 \\
\hline $\mathrm{Fe}$ & .0009 \\
\hline$k$ & 0.15 \\
\hline Mo & 0.0015 \\
\hline $\mathrm{Zn}$ & 0.0022 \\
\hline AI & 1.83 \\
\hline $\mathrm{Cl}$ & 0.41 \\
\hline $\mathrm{Ca}$ & 0.27 \\
\hline $\bar{F}$ & 0.01 \\
\hline $\mathrm{NH}_{4}$ & 0.048 \\
\hline $\mathrm{Ni}$ & 0.025 \\
\hline $\mathrm{PO}_{4}$ & 0.092 \\
\hline TOC & 1.54 \\
\hline$\overline{S r}$ & .001 \\
\hline Cs & .005 \\
\hline
\end{tabular}


WHC-SP-1004

This page intentionally left blank.

A-6 
WHC-SP-1004

APPENDIX B

B-1 
WHC-SP-1004

This page intentionally left blank. 
WHC-SP-1004

\section{APPENDIX B}

Calculate ezone use (a mole $\mathrm{coD} / \mathrm{mole}_{3} Q_{3}$ ) based on Fiqure 6.

Given:

also

$0 \mathrm{~g} 0_{3}$ feed at $10.85 \mathrm{~g} \mathrm{COD}$ in simulant

$30 \mathrm{~g} \mathrm{O}_{3}$ feed at $0.44 \mathrm{~g} \mathrm{COD}$ in simulant

Slope of the Tine is:

$$
\begin{gathered}
\frac{(10.85 \mathrm{~g} \mathrm{COD}-0.44 \mathrm{~g} \operatorname{COD}) /(16 \mathrm{~g} / \mathrm{mol} \mathrm{COD})}{\left.\left(0 \mathrm{~g} \mathrm{O} 0_{3}-30 \mathrm{~g} 0_{3}\right) / 48 \mathrm{~g} / \mathrm{mol} \mathrm{O}_{3}\right)} \\
\Rightarrow 104 \% \mathrm{O}_{3} \text { use } \leftarrow
\end{gathered}
$$

( $\therefore$ conservatively assume $>90 \%$ )

\section{Calculate scale-up of process}

Given:

$$
\begin{aligned}
& \text { Process rate } \quad 20 \times 10^{6} \mathrm{~L} / \mathrm{yr} \text { (diluted waste) } \\
& \text { Operation } \quad 180 \mathrm{~d} / \mathrm{yr} \\
& \text { Gas density } \quad 1 \mathrm{~L} \mathrm{O}_{2} / 1.3 \mathrm{~g} \mathrm{O}_{2}
\end{aligned}
$$

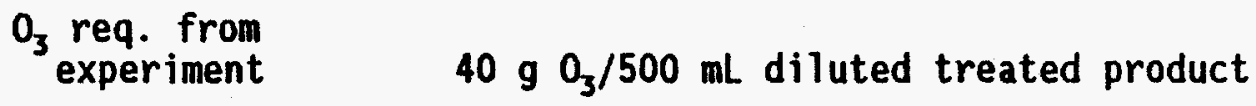

$$
\begin{aligned}
& \mathrm{O}_{3} \text { Concentration } \quad 10 \mathrm{wt. \%} \mathrm{O}_{3} \text { (experiment used } 8 \mathrm{wt} \% \text { ) } \\
& \begin{array}{l}
\text { Electricity to } \\
\text { make } \mathrm{O}_{3}
\end{array} \quad 0.8 \mathrm{kWh} / \mathrm{kg} \mathrm{O} \text { feed } \\
& \begin{array}{l}
\text { Laboratory reactor } \\
\text { volume }
\end{array} 50 \mathrm{~mL} \\
& \text { Laboratory gas } \\
& \text { flow rate } 48 \mathrm{~L} / \mathrm{h} \\
& \frac{\left(20 \times 10^{6} \mathrm{~L} \text { waste } / \mathrm{yr}\right)\left(40 \mathrm{~g} 0_{3}(0.5 \mathrm{~L} \text { waste })\left(100 \mathrm{~g} \mathrm{O}_{2}\right)\right.}{(180 \mathrm{~d} / \mathrm{yr})}\left(10 \mathrm{~g} \mathrm{O}_{3}\right) \\
& \Rightarrow 88,000 \mathrm{~kg} \mathrm{O} / \mathrm{d} \\
& \left(\therefore \text { conservatively assume } 90,000 \mathrm{~kg} \mathrm{O}_{2} / \mathrm{d} \leftarrow\right. \text { ) }
\end{aligned}
$$


WHC-SP-1004

Calculate scale-up of process (continued)

$$
\begin{array}{r}
\left(1 \mathrm{Lgas} / 1.3 \mathrm{~g} \mathrm{O}_{2}\right)\left(88 \times 10^{6} \mathrm{~g} 0_{2} / \mathrm{d}\right)(1 \mathrm{~d} / 24 \mathrm{~h}) \\
\Rightarrow 2.8 \times 10^{6} \mathrm{~L} 0_{2} / \mathrm{h}
\end{array}
$$

Direct ratio between laboratory equipment and full-scale plant

Experimental

$48 \mathrm{~L} / \mathrm{h}$

0.05 reactor volume
Full scale

$\frac{2.8 \times 10^{6} L_{0} O_{2} / \mathrm{h}}{\text { X reactor volume }}$

$X=2938-L$ full-scale reactor capacity

( $\therefore$ conservatively round to $4,000 \mathrm{~L}$ )

Power Requirements:

$(88,000 \mathrm{~kg} \mathrm{O} / \mathrm{d})\left(0.8 \mathrm{kWh} / \mathrm{kg} 0_{2}\right)$

$=70,400 \mathrm{kWh} / \mathrm{d}$ 
WHC-SP-1004

\section{DISTRIBUTION}

Number of copies

ONSITE

7

U.S. Department of Energy

Richland Field office

S. T. Burnum, Chief, Treatment

Branch, Tank Waste Disposal

Division (5)

A5-16

J. C. Peschong

A5-16

Public Reading Room

$\mathrm{H} 2-52$

Pacific Northwest Laboratory

Technical Files

$\mathrm{K} 1-11$

West inghouse Hanford Company

J. N. Appe1

$54-58$

H. Babad

R2-78

S. A. Barker

S4-55

W. B. Barton

L4-75

G. R. Bloom

[4-7]

D. R. Bratzel

[5-3]

A. L. Boldt

H5- 49

K. D. Boomer

H5-49

S. A. Colby (30)

L5-31

R. G. Cowan

M. D. Crippen

L5-31

J. M. Cruse

ᄂ5-63

C. H. Delegard

K. M. Eager

T6-09

J. S. Garfield

S4-58

W. 0. Greenhalgh

H5- 49

C. M. Haegen

L5-31

G. Hansrote

S4-58

H. D. Harmon

G6-12

R2-52

B. A. Higley

H5- 49

J. J. Holmes

L5-55

B. K. Horsager

S4-57

L. L. Humphreys

R2-31

R. A. Kirkbride

$54-58$

H. J. Klem

S4-58

G. T. McDonald

โ5-3]

W. C. Miller

S4-55

R. M. Orme

S4-58

D. C. Richardson

R2-31 
Westinghouse Hanford Company (cont.)

M. Schliebe

$54-25$

S. E. Seeman

LO-06

J. P. Sloughter

T6-07

D. J. Smith

K. B. Sowa

A. M. Stubbs

D. G. Sutherland

$54-54$

B5-24

L5-31

L4-72

W. I. Winters

J. C. Womack

Document Processing and

Distribution (2)

T6-50

LO-18

Central Files

L8-15

Information Release Administration (3)

L8- 04

Publications Services

A3-36

A2-25 